\title{
PEMANTAUAN RESPON KLINIS PENDERITA EPILEPSI GRAND MALL PADA LANSIA (Geriatri ) YANG MENDAPAT TERAPI FENITOIN DI APOTEK RAWAT JALAN RUMAH SAKIT "X" Malang
}

\author{
Rakhmadani Gadis Aprilianti ${ }^{1}$, Beta Herilla Sekti ${ }^{2}$ \\ ${ }^{1,2}$ Program Studi Farmasi Poltekkes RS dr. Soepraoen Malang \\ (Korespondensi: rakhmadaniG@gmail.com )
}

\begin{abstract}
ABSTRAK
Pendahuluan Angka prevalensi penderita epilepsi aktif berkisar antara 4-10 per 1000 penderita epilepsi (Beghi dan Sander, 2008). Bila jumlah penduduk Indonesia berkisar 220 juta, maka diperkirakan jumlah penderita epilepsi baru 250.000 per tahun. Rata-rata prevalensi epilepsi 8,2 per 1000 penduduk. Prevalensi epilepsi pada bayi dan anak-anak cukup tinggi, menurun pada dewasa muda dan pertengahan, kemudian meningkat lagi pada kelompok usia lanjut (Perhimpunan Dokter Spesialis Saraf Indonesia (PERDOSSI, 2011). Tujuan dalam penelitian ini untuk mengetahui persentase respon penderita epilepsi tipe grand mall lanjut usia yakni respon toksik berupa hiperplasia gusi, ruam kulit, vertigo, nistagmus, mual, sukar berbicara, ataksia. Penelitian ini bersifat observasional berdasarkan hasil kuesioner pasien epilepsi di apotek rawat jalan Rumah Sakit "X" Malang pada bulan April Oktober tahun 2019. Metode yang digunakan adalah deskriptif untuk melihat gambaran presentasi respon penderita epilepsi tipe grandmall. Instrumen penelitian berupa lembar pengambilan data dan kuesioner. Data akan dianalisis dan di dskripsikan berdasarkan hasil kuesioner. Hasil Berdasarkan hasil penelitian sekitar 27,06 \% responden menjawab Ya terjadi efek samping penggunaan fenitoin, sedangkan responden yang menjawab (Tidak) atau responden yang tidak muncul efek samping sesuai dengan kuisioner yaitu (78,94\%). Kesimpulan Berdasarkan hasil penelitian efek samping yang terjadi pada pasien dengan epilepsi tipe grandmall hanya minoritas, efek samping yang muncul paling banyak pada responden adalah pusing yaitu terjadi pada 7 responden, efek samping yang muncul lainya sempoyongan, berputarnya bola mata, sukar bicara.
\end{abstract}

Kata kunci: Terapi fenitoin, Epilepsi grandmall, Lansia

\section{Kesimpulan}

\begin{abstract}
Introduction The prevalence rate for active epilepsy patients ranges from 4-10 per 1000 epilepsy sufferers (Beghi and Sander, 2008). If the population of Indonesia is around 220 million, then the estimated number of new epilepsy sufferers is 250,000 per year. The


average prevalence of epilepsy is 8.2 per 1000 population. The prevalence of epilepsy in infants and children is quite high, decreases in young and middle adults, then increases again in the elderly group (Association of Indonesian Neurologist Specialists (PERDOSSI, 2011). The purpose of this study is to determine the percentage of epilepsy sufferers with the grand mall type elderly, namely toxic responses in the form of gum hyperplasia, skin rashes, vertigo, nystagmus, nausea, speech difficulties, ataxia.This study was observational based on the results of a questionnaire for epilepsy patients at an outpatient pharmacy at the " $\mathrm{X}$ " Hospital in Malang in April - October 2019. The research design is descriptive to see the presentation description of the response of patients with epilepsy type grandmall.Research instruments in the form of data collection sheets and questionnaires. The data will be analyzed and described based on the results of the questionnaire. Results based on the results of the study about $27.06 \%$ of respondents answered Yes there were side effects phenytoin, while respondents are answer (No) or respondents who did not have side effects in accordance with the questionnaire (78.94\%). Conclusion based on the results of the study the side effects that occur in patients with grandmall type epilepsy are only a minority, the side effects that appear most in the respondents are dizziness that occurs in 7 respondents, other side effects that appear to be tottering, turning of the eyeball, difficulty speaking

\section{PENDAHULUAN}

Epilepsi adalah suatu kelainan di otak yang ditandai adanya bangkitan epileptik yang berulang (lebih dari satu episode). International League Against Epilepsy (ILAE) dan International Bureau for Epilepsy (IBE) pada tahun 2005 merumuskan kembali definisi epilepsi yaitu suatu kelainan otak yang ditandai oleh adanya faktor predisposisi yang dapat mencetuskan bangkitan epileptik, perubahan neurobiologis, kognitif, psikologis dan adanya konsekuensi sosial yang diakibatkannya (Fisher, 2005)

Angka prevalensi penderita epilepsi aktif berkisar antara 4-10 per 1000 penderita epilepsi (Beghi dan Sander, 2008). Bila jumlah penduduk Indonesia berkisar 220 juta, maka diperkirakan jumlah penderita epilepsi baru 250.000 per tahun. Dari berbagai studi diperkirakan prevalensi epilepsi berkisar antara 0,5-4\%. Rata-rata prevalensi epilepsi 8,2 per 1000 penduduk. Prevalensi epilepsi pada bayi 
dan anak-anak cukup tinggi, menurun pada dewasa muda dan pertengahan, kemudian meningkat lagi pada kelompok usia lanjut (Perhimpunan Dokter Spesialis Saraf Indonesia (PERDOSSI, 2011)

Manajemen terapi pada lansia dengan epilepsi memerlukan perhatian khusus terutama karena perubahan terkait usia dalam hal farmakokinetika dan farmakodinamika obat antiepilepsi.

Parameter farmakokinetika seperti ikatan protein, distribusi dan eliminasi obat berubah dengan pertambahan usia, dan perubahan ini dapat menyulitkan pengaturan dan monitoring obat antiepilepsi pada lansia. Umumnya, lansia lebih sensitif terhadap efek farmakodinamika berbagai macam pengobatan, terutama yang berefek pada sistem saraf (Bourdet, 2005).

Kelainan sistemik yang mempercepat terjadinya kejang akut dapat melibatkan gangguan metabolik atau elektrolit, termasuk hipoglikemia, hiperglikemia, uremia, hiponatremia, hipokalsemia, hipotiroidisme, pneumonia, urosepsis dan sirosis hepatis. Banyak obat yang diberikan pada lansia dilaporkan dapat mempercepat kejang, misalnya : antipsikotik, antidepresan, antibiotik, teofilin, levodopa, diuretik tiazid dan ginko biloba. Kejang pertama tanpa penyebab yang jelas pada lansia lebih banyak berkembang menjadi kejang berulang dibandingkan pada pasien dewasa muda. Epilepsi biasanya didiagnosis setelah dua atau lebih kejang yang tidak diketahui penyebabnya (Brodie \& Kwan, 2005).

Berdasarkan uraian di atas, maka dalam penelitian ini akan dilakukan pemantauan respon penderita epilepsi grand mall lanjut usia setelah mengkonsumsi obat fenitoin di Rumah Sakit "X" Malang.

\section{METODE}

Instrumen yang digunakan dalam penelitian ini adalah kuesioner yang berisi serangkaian daftar pertanyaan tentang respon klinis yang terjadi selama pemakaian obat fenitoin pada responden. Dalam penelitian juga dilakukan wawancara yang bertujuan untuk memperjelas jawaban yang dituliskan dalam kuesioner.

Populasi dalam penelitian ini yaitu semua pasien rawat jalan penderita Epilepsi tipe grand mall lansia yang mendapatkan resep obat fenitoin 
di Apotek Rumah Sakit "X" Malang pada bulan April - Oktober 2019.

Setelah semua data hasil penyebaran kuesioner terkumpul, maka diklasifikasikan dan dikelompokkan sesuai dengan variabel yang diteliti. Analisa data menggunakan rumus :

$$
p=\frac{\sum n}{\sum N} \times 100 \%
$$

Keterangan :

$$
\begin{array}{ll}
\mathrm{p} & =\text { presentase } \\
\sum n & =\text { jawaban ya } / \text { tidak } \\
\sum N & =\text { jumlah responden }
\end{array}
$$

Berdasarkan analisis data tersebut akan didapatkan rata-rata sebagai gambaran respon klinis obat fenitoin pada penderita epilepsi.

\section{HASIL}

\section{Karakteristik Responden}

Penelitian dilakukan di RS. "X" Malang secara prospektif terhadap pasien epilepsi yang mendapat terapi fenitoin melalui wawancara. Berdasarkan penelitian terdapat 19 responden yang mengikuti ppenilitian ini yang mencakup pasien mandiri dan pasien asuransi BPJS. Berdasarkan dari karakteristik yang ditinjau dari jenis kelamin. Untuk jenis kelamin laki laki pada responden berjumlah 8 responden
(42\%). Sedangkan untuk jenis kelamin perempuan berjumlah 11 responden (58\%). Berikut ini grafik distribusi jumlah responden yang mengikuti penelitian dan menggunakan fenitoin du Rumah Sakit "X” Malang.

Grafik 4.1 Distribusi Jumlah Responden Yang Mengikuti Penelitian Dan Menggunakan Fenitoin Di Rumah Sakit "X" Malang.

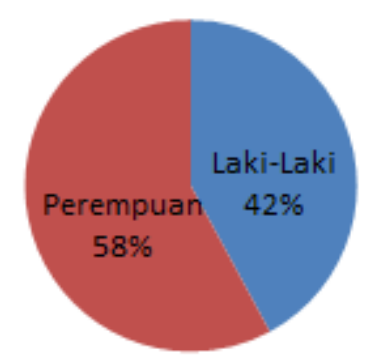

Pada penelitian ini menggunakan instrumen kuisioner melalui wawancara langsung dengan responden. Terdapat beberapa kendala pengisian kuisioner dikarenakan beberapa hal salah satunya terkait dengan kendala baca dan tulis sehingga perlu waktu dan penjelasan yang cukup dalam mengisi kuisioner, selanjutnya tidak semua pasien epilepsi menggunakan terapi fenitoin serta hak pasien untuk menolak dilakukan wawancara karena mungkinkondisi pasien yang tidak memungkinkan. Berikut ringkasan kuisioner efek samping penggunaan fenitoin. 
Tabel 4.1 Distribusi Ringkasan

Kuisioner Efek Samping Penggunaan

Fenitoin

\begin{tabular}{|c|c|}
\hline $\begin{array}{l}\text { Pertanyaan } \\
\text { Kuisioner }\end{array}$ & $\begin{array}{c}\text { Distribusi l } \\
\text { Jawaban } \\
\text { Responden } \\
\text { Ya }\end{array}$ \\
\hline 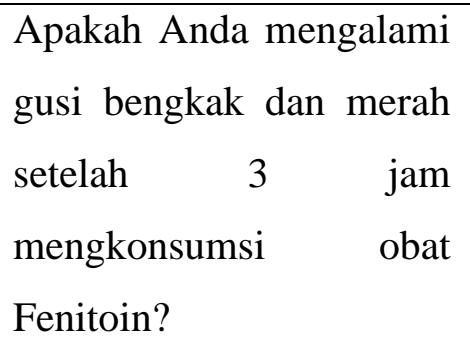 & 2 \\
\hline $\begin{array}{l}\text { Apakah Anda mengalami } \\
\text { kulit kemerahan setelah } 3 \\
\text { jam mengkonsumsi obat } \\
\text { Fenitoin? }\end{array}$ & 1 \\
\hline $\begin{array}{l}\text { Apakah Anda mengalami } \\
\text { pusing (mumet) setelah } 3 \\
\text { jam mengkonsumsi obat } \\
\text { Fenitoin? }\end{array}$ & 7 \\
\hline $\begin{array}{l}\text { Apakah Anda mengalami } \\
\text { pergerakan bola mata } \\
\text { secara cepat (bola mata } \\
\text { berputar) setelah _ jam } \\
\text { mengkonsumsi obat } \\
\text { Fenitoin? }\end{array}$ & 6 \\
\hline $\begin{array}{lrr}\text { Apakah } & \text { Anda mengalami } \\
\text { mual } & \text { (ingin } & \text { muntah) } \\
\text { setelah } & 3 & \text { jam }\end{array}$ & 3 \\
\hline
\end{tabular}

\begin{tabular}{|l|}
\hline $\begin{array}{l}\text { mengkonsumsi obat } \\
\text { Fenitoin? }\end{array}$ \\
$\begin{array}{l}\text { Apakah Anda mengalami } \\
\text { sukar berbicara setelah } 3 \\
\text { jam mengkonsumsi obat } \\
\text { Fenitoin? }\end{array}$ \\
\hline $\begin{array}{l}\text { Apakah Anda mengalami } \\
\text { sempoyongan setelah } 3 \\
\text { jam mengkonsumsi obat } \\
\text { Fenitoin? }\end{array}$ \\
Berdasarkan tabel \\
\hline
\end{tabular}

menunjukan Distribusi responden yang mengalami efek samping gusi bengkak setelah 3 jam mengkonsumsi fenitoin sebesar 2 responden (10\%), yang mengalami kulit kemerahan 1 responden (5\%), untuk responden yang mengalami pusing sebesar 7 responden (37\%). Responden yang mengalami efek samping yaitu pergerakan bola mata secara cepat (bola mata berputar) setelah mengkonsumsi fenitoin sebesar 6 responden (32\%), responden yang mengalami mual muntah 3 responden (16\%) sedangkan yanng mengalami efek samping sukar berbicara karena fenitoin 6 responden $(32 \%)$, serta yang 
mengalami efek samping sempoyongan berjumlah 6 responden (32\%).

Berdasarkan hasil perhitungan rekapitlasi kuisioner didapatkan presentase kejadian efek samping yang terjadi pada responden yang menggunakan terapi fenitoin adalah sebagai berikut:

Grafik 4.2 Distribusi presentase kejadian efek samping yang terjadi pada responden yang menggunakan terapi fenitoin di Rumah Sakit "X"Malang

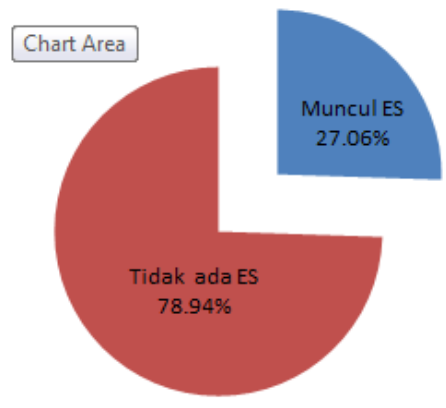

Berdasarkan Grafik 4.2 Terlihat angka kejadia efek samping sesuai dengan kuisioner yang terjadi pada responden yang menggunakan terapi fenitoin berdasarkan jawaban (Ya) responden yaitu sekitar 27,06 \%, sedangkan responden yang menjawab (Tidak) atau responden yang tidak muncul efek samping sesuai dengan kuisioner yaitu (78,94\%). Berdasarkan hasil penelitian efek samping yang muncul paling banyak pada responden adalah pusing yaitu terjadi pada 7 responden, efek samping yang juga banyak muncul pada responden diantaranya sempoyongan, berputarnya bola mata secara cepat dan sukar bicara yaitu masing masing terjadi pada 6 responden. Berdasarkan Harsaono (2011) Tujuan terapi farmakologi pada pasien epilepsi adalah menghilangkan atau menurunkan frekuensi serangan, meningkatkan kualitas hidup pasien, serta meminimalkan efek samping yang ditimbulkan. Sedangkan menurut Ikawati (2011).

Pemilihan terapi epilepsi dipilih sesuai dengan jenis epilepsi, efek samping yang spesifik dari obat antiepilepsi serta kondisi pasien. Penggunaan monoterapi lebih di anjurkan untuk mengurangi potensial efek samping yang dapat muncul,serta meningkatkan kepatuhan pasien. Adanya variasi individual pasien terhadap respon obat antiepilepsi sehingga diperlukan pemantauan ketat dan penyesuaian dosis. Berdasarkan hasil penelitian ini, diketahui pada masing masing individu yang terjadi efek samping sehingga hal ini dapat dijadikan dasar dan evaluasi dalam 
pengobatan pada masing-masing individu . Efek samping yang terjadi pada responden juga bervariasi, terdapat responden yang dapat mentolerir reaksi efek samping tersebut dan terdapat responden yang merasa terganggu dengan adanya efek samping tersebut, sehingga disarankan untuk responden untuk berdiskusi dengan dokter terkait efek samping yang terjadi agar dokter dapat mengevaluasi rejimen pengobatan yang sudah diberikan.

\section{KESIMPULAN}

Berdasarkan hasil penelitian sekitar $27,06 \%$ responden menjawab Ya terjadi efek samping penggunaan fenitoin, sedangkan responden yang menjawab (Tidak) atau responden yang tidak muncul efek samping sesuai dengan kuisioner yaitu (78,94\%). Berdasarkan hasil penelitian efek samping yang muncul paling banyak pada responden adalah pusing yaitu terjadi pada 7 responden, efek samping yang muncul lainya sempoyongan, berputarnya bola mata, sukar bicara.

\section{SARAN}

Rumah Sakit "X" Malang segera melakukan evaluasi efek samping yang terjadi pada pasien epilepsi lansia yang mendapat fenitoin sehingga dapat meminimalkan efek samping yang terjadi. .

\section{DAFTAR PUSTAKA}

Bourdet et al.2003. Pharmacologic Management of Epilepsy in Elderly. J.American Pharmaceutical Association. (Online).

(http://neurologyclinic.blogspot. com/2008/05/obat-antiepilepsipada-lansia.html/diakses 21 juni 2012).

Brodie JM, Kwan P. 2005. Epilepsy In Elderly People. Clinical Review. BMJ. Vol. 331; 1317-21. (Online).

(http://neurologyclinic.blogspot. com/2008/05/obat-antiepilepsipada-lansia.html/diakses 21 juni 2012).

Dipiro, J.T., et al. 2008. Pharmacotherapy: A Pathophysiologic Approach 7th Edition. United States of America: The McGraw-Hill Companies, Inc Fisher, R. S., Boas, W. V. E., Blume, W., Elger, C., Genton, P., Lee, 
P. \& Engel, J. 2005. Epileptic

Seizures And Epilepsy:

Definitions Proposed By The

International League Against

Epilepsy (Ilae) And The

International Bureau For

Epilepsy (Ibe). Epilepsia, 46, 470-472.

Harsono. 2011. Epilepsi. Yogyakarta:

Gadjah Mada University Press

Ikawati,Z. 2011. Farmakoterapi

Penyakit Sistem Saraf Pusat.

Yogyakarta : Bursa Ilmu

Karangkajen. Hal 85-102.

Lacy, Charles F. ,dkk. 2009. Drug Information Handbook $17^{\text {th }}$ edition. America: Lexy Companies

Leppik MD. 2001a. Epilepsy in Elderly in Contemporary Diagnosis and Management of the Patient with
Epilepsy. Handbook in Health Care, Newtown, Pennsylvania. USA.

(Online).

(http://neurologyclinic.blogspot. com/2008/05/obat-antiepilepsipada-lansia.html/diakses $\quad 20$ Maret 201).

Price dan Wilson. 2006. Patofisiologi: Konsep Klinis Prose-Proses Penyakit. Ed: 6. Jakarta: EGC

Shorvon SD. 2005. Handbook of Epilepsy Treatment Forms, Causes and Therapy in Children and Adults.2 ${ }^{\text {nd }}$ ed. America: Blackwell Publishing Ltd Tjay, Tan Hoan. 2002. Obat-Obat Penting. Jakarta : Elex Media Komputindo. 